\title{
Author Correction: A tool for functional brain imaging with lifespan compliance
}

Ryan M. Hill, Elena Boto, Niall Holmes, Caroline Hartley (1), Zelekha A. Seedat, James Leggett, Gillian Roberts, Vishal Shah, Tim M. Tierney, Mark W. Woolrich, Charlotte J. Stagg (D, Gareth R. Barnes (D), Richard Bowtell, Rebeccah Slater (1) \& Matthew J. Brookes

Correction to: Nature Communications https://doi.org/10.1038/s41467-019-12486-x, published online 05 November 2019.

The original version of this Article contained an error in the spelling of the author Richard Bowtell, which was incorrectly given as Richard R. Bowtell. This has now been corrected in both the PDF and HTML versions of the Article.

Published online: 04 December 2019

\begin{abstract}
(c) (i) Open Access This article is licensed under a Creative Commons Attribution 4.0 International License, which permits use, sharing, adaptation, distribution and and indicate if changes were made. The images or other third party material in this article are included in the article's Creative Commons license, unless indicated otherwise in a credit line to the material. If material is not included in the article's Creative Commons license and your intended use is not permitted by statutory regulation or exceeds the permitted use, you will need to obtain permission directly from the copyright holder. To view a copy of this license, visit http://creativecommons.org/licenses/by/4.0/.
\end{abstract}

(C) The Author(s) 2019 